\title{
Penapisan Virtual Senyawa-Senyawa dalam Famili Zingiberaeae sebagai Antiinflamasi Menggunakan Protokol EE_COX2_V.1.0
}

Penulis

Afiliasi

\author{
Esti Mulatsari ${ }^{*}$, Esti Mumpuni, Feriza Sandayu
}

Fakultas Farmasi, Universitas Pancasila, Jakarta,12640, farmasi@ffup.org, Indonesia

\section{Kata Kunci \\ O Penapisan virtual \\ $\rightarrow$ Cyclooxygenase-2, \\ ○ Zingiberaceae}

Diterima 23 Maret 2017

Direvisi 18 Mei 2017

Disetujui 19 Juli 2017

*Penulis korespondensi Esti Mulatsari

Fakultas Farmasi, Universitas Pancasila, Jakarta,12640, Indonesia

Email :

estimulatsari@gmail.com

\section{ABSTRAK}

Berbagai penelitian tentang sifat-sifat anti-inflamasi dan anti-kanker dari berbagai senyawa dalam tanaman familia Zingiberaceae telah dilakukan baik secara in vivo maupun in vitro. Enzim yang diinduksi dan diekspresikan pada sel-sel inflamasi dan kanker dianggap sebagai target obat yang ideal untuk menghambat peradangan dan tumorgenesis, salah satunya adalah enzim siklooksigenase-2 (COX-2). Dalam penelitian ini telah dilakukan penapisan virtual senyawa dalam tanaman Kaemferia galanga, Curcuma domestica Val., Zingiber officinale dan Curcuma xanthorrhiza. Tujuan dari penelitian ini adalah untuk mengetahui aktivitas senyawa-senyawa tersebut sebagai penghambat enzim COX-2 secara in-silico. Penelitian ini menggunakan EE_COX2_V.1.0, protokol Structure Based Virtual Screening (SBVS) yang telah divalidasi oleh Mumpuni et al. 2014. Protokol EE_COX2_V.1.0 menggunakan berbagai aplikasi terintegrasi seperti SPORES, PLANTS, BkChem, OpenBabel dan PyMOL. Elusidasi moda ikatan dilakukan terhadap senyawa representatif aktif dan tidak aktif untuk melihat interaksi asam amino dalam binding site senyawa. Berdasarkan skor ChemPLP sebagai hasil dari simulasi docking yang dilakukan pada 27 senyawa, ada 3 senyawa yang berpotensi aktif dalam menghambat COX-2, senyawa tersebut antara lain 2-butil-3- (4-metoksifenil) -2- asam propenoat dengan 6 residu asam amino aktif, 6-shogaol dengan 10 residu asam amino aktif dan desmetoksikurkumin dengan 4 residu asam amino yang aktif.

\section{PENDAHULUAN}

Beberapa penelitian telah dilakukan, baik secara in vivo maupun in vitro, mengenai aktivitas anti-inflamasi dan anti-kanker dari berbagai senyawa dalam empat tanaman berbeda dari familia Zingiberaceae, tanaman tersebut antara lain : kencur (Kaempferia galanga) (Hasanah et al. 2011) kunyit (Curcuma domestica Val.) (Muniroh et al. 2010), jahe (Zingiber officinale (L.) Rosc.) (Hernani dan Winarti 2008) temulawak (Curcuma xanthorrhiza) (Cahyono et al. 2011). Dasar pemilihan keempat tanaman tersebut karena banyak ditemukan di Indonesia, mudah didapat dan harga terjangkau.

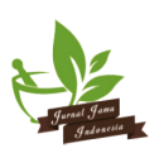


Enzim yang diinduksi dan diekspresikan pada sel inflamasi dan sel kanker dianggap sebagai target obat yang ideal untuk menghambat inflamasi dan tumorgenesis, salah satunya adalah enzim siklooksigenase (COX). Enzim COX terdiri dari dua isoenzim yaitu COX-1 dan COX-2. Enzim COX-1 berperan dalam memelihara fisiologi normal dan homeostasis, sedangkan COX-2 merupakan enzim yang terinduksi pada sel yang mengalami inflamasi oleh sitokin, endotoksin, dan faktor pertumbuhan. Ekspresi COX-2 dapat memacu terjadinya kanker melalui peningkatan produksi prostaglandin yang akan meningkatkan proliferasi sel kanker. Oleh karena itu, menjadikan enzim COX-2 sebagai target merupakan strategi penemuan obat yang tepat dan layak dilakukan. Penemuan obat golongan coxib (penghambat selektif enzim siklooksigenase-2) merupakan terobosan baru dalam terapi inflamasi dan kanker (Meiyanto 2011). Hal ini terlihat pada mekanisme kerja celecoxib yang menginduksi apoptosis, menekan proliferasi, dan mengurangi angiogenesis serta melemahkan invasi sel kanker lambung (Eko 2012).

Studi komputasi dikenal dengan terminologi in silico merupakan analog in vivo dan in vitro yang menggunakan aplikasi komputer, sehingga waktu dan biaya menjadi lebih efisien (Navya et al. 2011). Pada penelitian ini akan dilakukan uji in silico senyawasenyawa yang terkandung dalam famili Zingiberaceae melalui proses penapisan virtual dengan protokol tervalidasi EE_COX2_V.1.0. Protokol EE_COX2_V.1.0 telah dinyatakan valid dan dapat digunakan untuk mengidentifikasi senyawa inhibitor COX-2, dengan didapatkan nilai Root Mean Square Deviation (RMSD) sebesar 0,525 A. Berdasarkan nilai RMSD yang diperoleh, protokol ini dikategorikan "sangat baik" oleh Huang et al. (2006) dan Yuniarti et al. (2011). Dalam penelitian ini, digunakan protokol SBVS EE_COX2_V.1.0 untuk melakukan penapisan virtual senyawa uji dengan target enzim COX-2, struktur kristal enzim COX-2 ini diperolah dari data base Protein Data Bank (PDB) dengan kode 3LN1.pdb dengan resolusi : $2.40 \AA$ A. Hasil penelitian ini diharapkan dapat diperoleh senyawa senyawa dalam tanaman famili Zingiberaceae yang mempunyai aktivitas sebagai penghambat COX-2 secara in-silico serta mengetahui moda ikatan yang terbentuk antara senyawa dan enzim, sehingga bisa dianalisis lebih lanjut sebagai kandidat obat golongan coxib (penghambat COX-2).

\section{METODE \\ Bahan}

Struktur 2D dari senyawa uji yaitu senyawa senyawa dalam tanaman : kencur (Kaempferia galanga) antara lain senyawa etil p-metoksisinamat, etil sinamat, 2,4,6-trimetil oktana dan 2-butil-3-(4metoksifenil) 2-asam propenoat (Hasanah et al. 2011); kunyit (Curcuma domestica Val.) yaitu senyawa sinamil tiglat, eukaliptol, metilol pinen, seskuifelandren, 1felandren, dan aril-turmeron (Muniroh et al. 2010); jahe (Zingiber officinale (L.) Rosc.) yaitu senyawa 4gingerol, 6-gingerol, 8- gingerol, 10-gingerol, 6-shogaol, 8-shogaol, 10-shogaol, 6-paradol, 8-paradol, zingiberen, dan $\alpha$-farnesen (Hernani \& Winarti 2008); temulawak (Curcuma xanthorrhiza) yaitu senyawa kurkumin, desmetoksikurkumin, bisdesmetoksikurkumin, kamfer, borneol, dan xanthorrizol (Cahyono et al. 2011). Struktur 2D Senyawa pembanding ZINC03814547 yang terintegrasi dalam protokol EE_COX2_V.1.0.

\section{Perangkat Keras}

Satu set komputer dengan prosesor Intel ${ }^{\otimes}$ Core ${ }^{\text {тм }}$ i3-2350 CPU @2.30 GHz, RAM 4 GB, 64 bit Operating System.

\section{Perangkat Lunak}

Sistem operasi LINUX Ubuntu 10.04 LTS - the lucid lynx- released in April 2010 yang dapat diunduh di: http://releases.ubuntu.com/lucid/, SPORES (Structure PrOtonation and REcognition System) Versi untuk LINUX dari : $\quad$ http://www.tcd.unikonstanz.de/index.php, PLANTS (Protein-Ligand ANT System) 1.2 Versi untuk LINUX dari : http://www.tcd.uni-konstanz.de/index.php, BkChem 0.13.0 dari : http://www.BkChem.zirael.org/index.html, Open Babel Versi 2.3.0 dari : http://openbabel.org/, PyMOL (Python-Enhanced Molecular Graphics Tool) dari : http://www.PyMOL.org/, Protokol SBVS EE_COX2_V.1.0, Software statistical analysis R i386 3.0.1 dari : www.r-project.com.

\section{Konstruksi senyawa uji dengan Software BkChem}

Pada terminal digunakan aplikasi EE_COX2_V.1.0 dengan moda command line interface dengan perintah sebagai berikut ./EECOX2_V.1.0.sh. Secara otomatis akan muncul jendela BkChem. Langkah berikutnya adalah konstruksi senyawa uji menggunakan software $B k C h e m$, di jendela BkChem tersebut digambar struktur

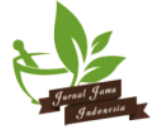


2D senyawa uji, Setelah selesai menggambar struktur 2D senyawa uji berkas dieksport dengan klik File $>$ Export $>$ Molfile agar data yang disimpan dalam bentuk teks dapat di baca oleh PLANTS maupun aplikasi lainnya. Pastikan ada setidaknya satu bagian dari gambar struktur 2D yang dipilih sebelum prosedur export ini dijalankan jika tidak ingin prosedur berhenti dan muncul pesan galat. Jika prosedur benar akan muncul jendela Export Molfile yang sudah di setting dengan nama "uji.mol". Langsung klik "save". Lalu klik tanda silang (tutup) di ujung kiri atas. Selanjutnya akan muncul jendela konfirmasi dan klik "close". Setelah itu aplikasi EE_COX2_V.1.0 akan memberikan hasil berupa score ChemPLP senyawa uji dan ligan pembanding. Langkah-langkah tersebut dilakukan dengan replikasi setidaknya 3 kali. Selanjutnya dilakukan uji statistika one-tailed t-test menggunakan aplikasi statistik versi $\mathrm{R}$ i386 3.0.1. Dilakukan pula uji kontrol positif menggunakan senyawa dari obat golongan coxib.

\section{Elusidasi Moda Ikatan}

Elusidasi moda ikatan dilakukan dengan aplikasi PyMOL untuk senyawa representatif aktif dan tidak aktif yang berasal dari tanaman yang sama, kemudian senyawa representatif aktif divisualisasi secara 3D dan ditentukan sebagai senyawa rekomendasi yang dapat dikembangkan untuk diteliti lebih lanjut.

\section{HASIL DAN PEMBAHASAN}

\section{Penapisan Virtual Senyawa Uji}

Penapisan virtual senyawa uji dimulai dengan menyiapkan sejumlah 27 senyawa uji dan sebuah ligan pembanding. Masing-masing senyawa uji digambar menggunakan aplikasi BkChem yang terbuka secara otomatis saat menjalankan protokol SBVS. Ligan pembanding yang digunakan ialah ZINC03814547. Ligan pembanding tersebut telah terintegrasi dalam protokol SBVS. Proses penapisan virtual dilakukan untuk menghasilkan score ChemPLP. Score tersebut merupakan energi total yang dihitung dari satu kali proses docking (Huang et al. 2006). Setiap satu kali simulasi docking pada penapisan virtual berlangsung dihasilkan masing-masing satu score senyawa uji dan ligan pembanding. Score tersebut dapat berbeda pada simulasi berikutnya meskipun menggunakan senyawa uji dan ligan pembanding yang sama. Oleh karena itu, perlu dilakukan replikasi dalam tahap ini.

Langkah selanjutnya, score hasil simulasi docking dari 27 senyawa uji dibandingkan dengan ligan pembanding. Senyawa uji dikatakan aktif secara in silico pada binding pocket COX-2 apabila memiliki score yang lebih kecil (lebih negatif) dibandingkan score ligan pembanding, hal ini berarti senyawa tersebut memiliki kestabilan yang lebih baik dalam berikatan dengan reseptor. Hasil simulasi docking berikut keterangan aktivitasnya secara in silico disajikan dalam Tabel 1. Tabel 1 menunjukkan bahwa berdasarkan score ChemPLP yang diperoleh, dari 27 senyawa uji hanya terdapat 3 senyawa uji yang aktif pada binding pocket COX-2 secara in silico, yakni senyawa 2-butil-3-(4metoksifenil)-2-asam propenoat yang terkandung dalam rimpang kencur dengan rata-rata score sebesar 652.8467, senyawa 6-shogaol yang terkandung dalam rimpang jahe dengan rata-rata score -385.4167 dan senyawa desmetoksikurkumin yang terkandung dalam rimpang kunyit dengan rata-rata score -385.1950. Perhitungan ChemPLP juga dilakukan pada senyawa golongan etoricoxib dan celecoxib sebagai control positif dengan senyawa pembanding ZINC03814547. Skor yang didapat dari etoricoxib adalah -392.1117 sedangkan skor ligan pembanding adalah -380.8727. Skor yang didapat dari celecoxib adalah -398.1853 skor ligan pembanding adalah -380.8700 .

Selanjutnya dilakukan analisa secara statistik onetailed paired t-test pada tiap score senyawa uji dan ligan pembanding yang telah didapat. Pada pengujian secara statistik, apabila didapatkan $p$-value kurang dari 0.05 pada taraf kepercayaan 95\%, maka dapat dinyatakan rata - rata score senyawa uji signifikan atau bermakna yang berarti dapat mewakili keseluruhan populasi. Senyawa 2-butil-3-(4- metoksifenil)-2-asam propenoat memiliki $p$-value sebesar 0.000008 , senyawa 6-shogaol memiliki $p$-value sebesar 0.0498 dan senyawa desmetoksikurkumin memiliki $p$-value sebesar 0.0129 . Berdasarkan pengujian statistik terhadap 27 senyawa uji, hanya ketiga senyawa tersebut yang memiliki $p$-value kurang dari 0.05 . Hal ini menunjukkan bahwa ketiga senyawa tersebut memiliki aktifitas sebagai penghambat COX-2 yang aktif.

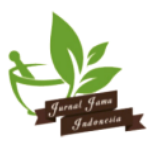


Tabel 1 Nilai ChemPLP dan aktivitas penghambatan COX-2 senyawa uji dan pembanding

\begin{tabular}{|c|c|c|c|}
\hline \multirow[b]{2}{*}{ Nama Senyawa Uji } & \multicolumn{2}{|c|}{ Rata-rata score ChemPLP } & \multirow{2}{*}{$\begin{array}{c}\text { Aktivitas } \\
\text { penghambatan coX-2 } \\
\text { secara in silico }\end{array}$} \\
\hline & Uji & Pembanding & \\
\hline \multicolumn{4}{|l|}{ Kencur (Kaemferia galanga) } \\
\hline Etil p- metoksisinamat & -360.1750 & -380.9100 & Tidak aktif \\
\hline Etil sinamat & -352.8650 & -380.8813 & Tidak aktif \\
\hline 2,4,6- trimetil oktana & -5.9054 & -380.8720 & Tidak aktif \\
\hline $\begin{array}{l}\text { 2-butil-3-(4-metoksifenil)-2-asam } \\
\text { propenoat }\end{array}$ & -652.8467 & -380.8707 & Aktif \\
\hline \multicolumn{4}{|l|}{ Kunyit (Curcuma domestica Val.) } \\
\hline Sinamil tiglat & -353.4030 & -380.8660 & Tidak aktif \\
\hline Kurkumin & -373.7450 & -380.8763 & Tidak aktif \\
\hline Eukaliptol & -149.2933 & -380.8680 & Tidak aktif \\
\hline Metilol pinen & -301.9810 & -380.8710 & Tidak aktif \\
\hline Seskuifelan dren & -87.4063 & -380.7734 & Tidak aktif \\
\hline 1-felandren & 266.4500 & -380.8853 & Tidak aktif \\
\hline Aril- turmeron & -355.1623 & -380.9140 & Tidak aktif \\
\hline \multicolumn{4}{|l|}{ Jahe (Zingiber officinale (L) Rosc.) } \\
\hline 4-gingerol & -375.0373 & -380.8783 & Tidak aktif \\
\hline 6-gingerol & -377.8817 & -380.8930 & Tidak akif \\
\hline 8-gingerol & -376.5933 & -380.8863 & Tidak Aktif \\
\hline 6-shogaol & -385.4167 & -380.8817 & Aktif \\
\hline 10- gingerol & -377.0567 & -380.8613 & Tidak aktif \\
\hline 8-shogaol & -376.2560 & -380.8910 & Tidak aktif \\
\hline 10- shogaol & -378.3980 & -380.8807 & Tidak aktif \\
\hline 6-paradol & -374.6620 & -380.8860 & Tidak aktif \\
\hline 8-paradol & -380.1687 & -380.8853 & Tidak aktif \\
\hline Zingiberen & -87.1412 & -380.7567 & Tidak aktif \\
\hline Farnesen & -16.2445 & -380.8707 & Tidak aktif \\
\hline \multicolumn{4}{|l|}{ Temulawak (Curcuma xanthorrhiza) } \\
\hline Kurkumin & -373.7450 & -380.8763 & Tidak aktif \\
\hline Demetoksikurkumin & -385.1950 & -380.8993 & Aktif \\
\hline Bisdemetoksikurkum in & -370.6513 & -380.8573 & Tidak aktif \\
\hline Kamfer & -275.1710 & -380.8957 & Tidak aktif \\
\hline Borneol & -280.7877 & -380.8783 & Tidak aktif \\
\hline Xanthorrh izol & -288.2827 & -382.6080 & Tidak aktif \\
\hline \multicolumn{4}{|l|}{ Obat Golongan Celocoxib } \\
\hline Etoricoxib & -392.1117 & -380.8727 & Aktif \\
\hline Celecoxib & -398.1853 & -380.8700 & Aktif \\
\hline
\end{tabular}

\section{Elusidasi Moda Ikatan Senyawa Representatif}

Senyawa 2-butil-3-(4-metoksifenil)-2-asam propenoat yang terkandung dalam rimpang kencur, 6shogaol yang terkandung dalam rimpang jahe dan senyawa desmetoksikurkumin yang terkandung dalam rimpang kunyit dijadikan senyawa representatif aktif, karena memiliki score lebih kecil (lebih negatif) dari score ligan pembanding. Dilakukan pula pemilihan masing-masing satu senyawa dengan score terbesar (kurang negatif) yang berasal dari tanaman yang sama dengan senyawa representatif aktifnya untuk dijadikan sebagai senyawa representatif tidak aktif. Pada rimpang kencur, dipilih senyawa 2,4,6-trimetil oktana, pada rimpang jahe dipilih senyawa fernasen dan pada rimpang kunyit dipilih senyawa kamfer sebagai senyawa representatif tidak aktif. Selanjutnya dilakukan elusidasi moda ikatan terhadap senyawa representatif aktif maupun tidak aktif. 
Langkah elusidasi yang terjadi di dalam binding pocket dilakukan dengan memanfaatkan aplikasi PyMOL. Langkah ini dilakukan untuk melihat interaksi asam-asam amino dalam binding site senyawa representatif aktif maupun tidak aktif. Berdasarkan hasil elusidasi yang dilakukan terhadap senyawa representatif yang berasal dari tanaman kencur di dalam binding site-nya, didapatkan 27 interaksi asam amino pada senyawa representatif aktif dan 30 interaksi asam amino pada senyawa representatif tidak aktif. Pada senyawa representatif aktif yang berasal dari rimpang jahe, didapatkan 20 interaksi asam amino dan 18 interaksi asam amino pada senyawa representatif tidak aktif di dalam binding site-nya. Pada senyawa representatif aktif yang berasal dari rimpang kunyit didapatkan 25 interaksi asam amino pada senyawa representatif aktif dan 22 interaksi asam amino pada senyawa representatif tidak aktif. Residuresidu asam amino yang berinteraksi dengan senyawa representatif dapat dilihat di Tabel 2 .

Residu asam amino senyawa representatif aktif yang berinteraksi dengan senyawa representatif tidak aktif maka residu asam amino tersebut tidak berpengaruh atau bahkan berpengaruh negatif pada aktifitas senyawa representatif aktif. Residu asam amino yang terdapat pada senyawa representatif aktif, terdapat residu asam amino yang tidak terdapat senyawa representatif tidak aktif, residu asam amino tersebut berpengaruh secara determinan terhadap aktifitas pemnghambatan COX-2 senyawa representatif aktif. Pada senyawa representatif aktif yang berasal dari rimpang kencur terdapat 6 residu asam amino aktif yaitu: LEU338, LEU370, PHE367, PHE504, SER323 dan SER516. Adapun senyawa representatif aktif yang

Tabel 2 Residu asam amino senyawa representatif aktif dan tidak aktif

\begin{tabular}{|c|c|c|c|c|}
\hline No. & Tanaman Asal & \multicolumn{2}{|c|}{$\begin{array}{c}\text { Senyawa Representatif } \\
\text { (Aktif / Tidak Aktif) }\end{array}$} & Asam Amino yang Berikatan \\
\hline \multirow[t]{2}{*}{1} & $\begin{array}{l}\text { Kencur } \\
\text { (Kaempferia } \\
\text { galanga) }\end{array}$ & $\begin{array}{l}\text { 2-butil-3-(4- } \\
\text { metoksifenil)- 2-asam } \\
\text { propenoat }\end{array}$ & Aktif & $\begin{array}{l}\text { ARG491, ALA502, ALA430, GLN176, GLY512, } \\
\text { MET523, PHE264, PHE506, SER339, HIS75, HIS77, } \\
\text { ILE501, ILE503, LEU338, LEU370, MET508, } \\
\text { PHE367, PHE504, SER323, SER516, SER440, } \\
\text { TYR334, TYR341, TYR371, VAL330, VAL335, } \\
\text { VAL509. }\end{array}$ \\
\hline & & 2,4,6-trimetil oktana & Tidak Aktif & $\begin{array}{l}\text { ARG106, ARG491, ALA502, ALA430, GLN176, } \\
\text { GLN559, GLY512, MET523, MET332, PHE264, } \\
\text { PHE506, SER339, HIS75, HIS77, ILE501, ILE503, } \\
\text { TRP338, TRP380, MET508, PHE776, PHE505, } \\
\text { SER339,SER513, SER440, LEU334, LEU341, } \\
\text { TYR371, VAL330, VAL335, VAL509. }\end{array}$ \\
\hline \multirow[t]{2}{*}{2} & $\begin{array}{l}\text { Jahe (Zingiber } \\
\text { officinale (L) Rosc.) }\end{array}$ & 6-shogaol & Aktif & $\begin{array}{l}\text { ARG106, ARG495, ALA504, ALA513, GLN178, } \\
\text { GLN336, GLN506, GLY505, GLY512, HIS75, ILE331, } \\
\text { ILE503, TYR103, TYR338, LEU345, LEU370, } \\
\text { LEU517, VAL330, VAL335, MET99. }\end{array}$ \\
\hline & & Farnesen & Tidak Aktif & $\begin{array}{l}\text { ARG106, ARG499, ALA502, ALA513, GLY505, } \\
\text { GLY512, MET99, MET508, PHE504, PRO514, } \\
\text { SER339, SER516, TYR103, TYR338, TRP373, } \\
\text { VAL330, VAL335, VAL509. }\end{array}$ \\
\hline \multirow[t]{2}{*}{3} & $\begin{array}{l}\text { Kunyit (Curcuma } \\
\text { domestica Val.) }\end{array}$ & Desmetoksikurkumin & Aktif & $\begin{array}{l}\text { ARG106, ARG499, ALA502, ALA513, GLN178, } \\
\text { GLY512, HIS75, ILE503, LEU338, LEU345, LEU370, } \\
\text { LEU517, LEU517, MET508, PHE367, PHE504, } \\
\text { SER339, SER516, TYR790, TYR341, TRP331, } \\
\text { TRP373, VAL330, VAL335, VAL509 }\end{array}$ \\
\hline & & Kamfer & Tidak aktif & $\begin{array}{l}\text { ARG499, ALA502, ALA513, GLN178, GLY512, } \\
\text { HIS75, ILE503, LEU338, LEU370, LEU517, LEU517, } \\
\text { MET508, PHE367, PHE504, SER339, SER516, } \\
\text { TYR341, TYR371, TRP373, VAL330, VAL335, } \\
\text { VAL509 }\end{array}$ \\
\hline
\end{tabular}


berasal dari rimpang jahe terdapat 10 residu asam amino aktif, yaitu : ARG495, ALA504, GLN178, GLU506, HIS75, ILE331, ILE503, LEU345, LEU370 dan LEU517 dan senyawa representatif aktif yang berasal dari rimpang kunyit terdapat 4 residu asam amino aktif yaitu: ARG106, LEU345, TYR790 dan TRP331.

Pada proses elusidasi ini dapat diketahui pula bahwa sebuah ligan memiliki binding site dengan asam amino tertentu pada reseptor, dimana dalam penelitian ini berupa enzim COX-2. Interaksi liganreseptor terjadi karena ada ikatan hidrogen, ikatan Van Der Waaals, dan atau interaksi elektrostatik. Dengan menggunakan aplikasi PyMOL, ikatan hidrogen antara ligan dengan asam amino yang terdapat pada binding pocket reseptor dapat diketahui. Jarak ikatan ligan dengan asam amino reseptor akan mempengaruhi afinitas ikatan antara ligan dan reseptor. Semakin kecil jarak ikatan, maka akan semakin besar afinitas ikatan antara ligan dan reseptor. Setelah proses elusidasi moda ikatan terhadap senyawa reresentatif aktif dan senyawa representatif tidak aktif, kemudian dilakukan visualisasi secara 3D senyawa representatif aktif menggunakan apikasi PyMOL. Visualisasi 3D senyawa senyawa representatif aktif ditunjukkan Gambar 1, Gambar 2 dan Gambar 3.

\section{KESIMPULAN}

Berdasarkan score ChemPLP dari proses penapisan virtual yang dilakukan, dapat disimpulkan ada 3 senyawa yang diprediksi aktif sebagai penghambat COX-2 secara in silico, senyawa - senyawa tersebut antara lain 2-butil-3-(4- metoksifenil)-2-asam propenoat yang berasal dari tanaman kencur (Kaempferia galanga) dengan score ChemPLP sebesar 652.8467, senyawa 6 -shogaol yang berasal dari tanaman jahe (Zingiber officinal) dengan score ChemPLP sebesar -385.4167 dan senyawa desmetoksikurkumin yang berasal dari tanaman kunyit (Curcuma domestica Val.) dengan score ChemPLP sebesar -385.1950 .
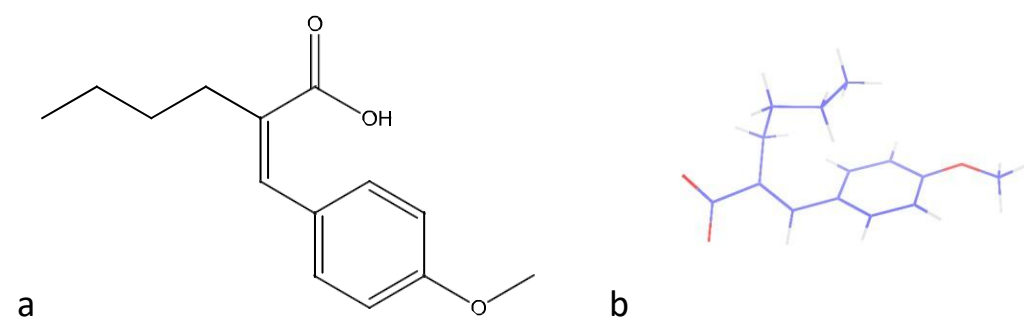

a

b

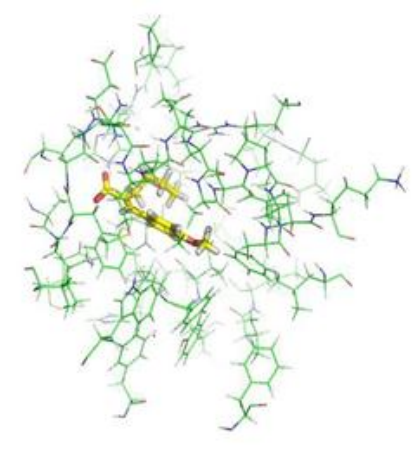

C

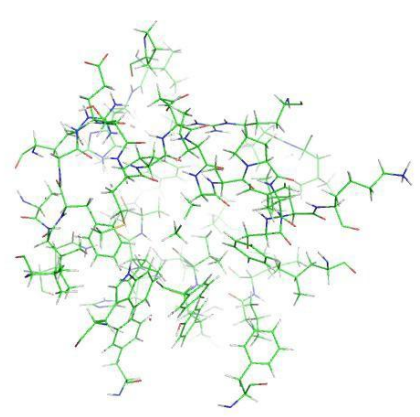

Gambar 1 Tampilan senyawa representatif aktif yang berasal dari rimpang kencur.( 2-butil-3-(4- metoksifenil)2-asam propenoat) a. Tampilan 2D, b. Tampilan 3D, c. Posisi senyawa dalam binding pocket COX-2 
a<smiles>CCCCC/C=C/C(=O)CCc1ccc(O)c(O)c1</smiles>

b

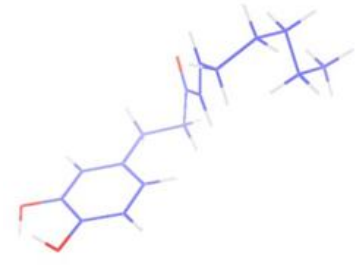

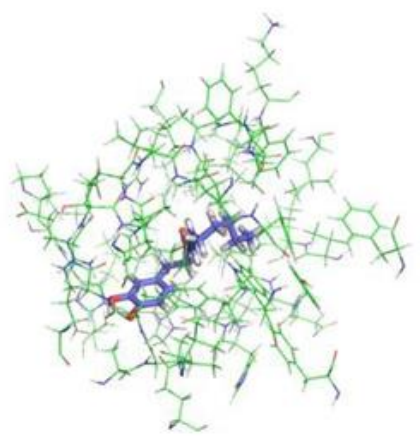

C

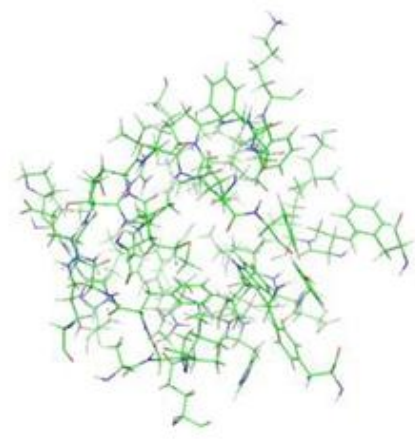

Gambar 2 Tampilan senyawa representatif aktif yang berasal dari rimpang jahe.( 6-shogaol) a. Tampilan 2D, b. Tampilan 3D, c. Posisi senyawa dalam binding pocket COX-2<smiles>Cc1ccc(/C=C/C(=O)CC(=O)/C=C/c2ccc(O)c(CO)c2)cc1</smiles>

a

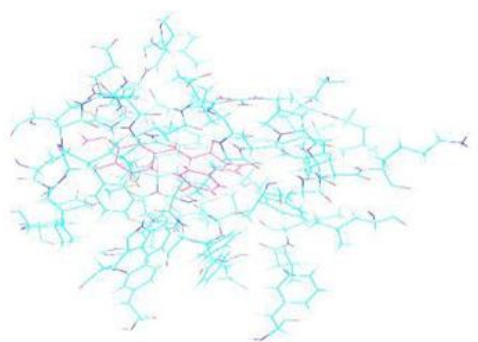

b

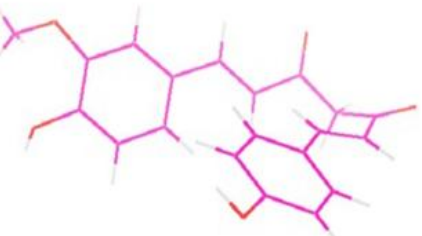

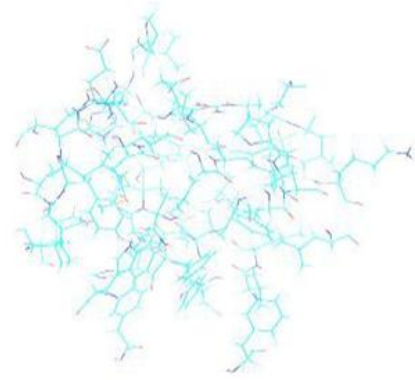

C

Gambar 3 Tampilan senyawa representatif aktif yang berasal dari rimpang kunyit (desmetoksikurkumin) a.Tampilan 2D, b. Tampilan 3D, c. Posisi senyawa dalam binding pocket COX-2

Berdasarkan proses elusidasi moda ikatan yang dilakukan terhadap senyawa 2-butil-3-(4-metoksifenil)2-asam propenoat, 6-shogaol dan desmetoksikurkumin dapat diketahui residu asam-asam amino yang memberikan peran sebagai penghambat COX-2. Pada senyawa 2-butil-3-(4-metoksifenil)-2-asam propenoat terdapat 6 residu asam amino dari tanaman kencur, residu asam-asam amino tersebut, yaitu: : LEU338,

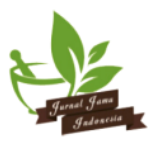


LEU370, PHE367, PHE504, SER323 dan SER516, pada senyawa 6-shogaol terdapat 10 residu asam amino, yaitu: ARG495, ALA504, GLN178, GLU506, HIS75, ILE331, ILE503, LEU345, LEU370 dan LEU517, sedangkan pada senyawa desmetoksikurkumin terdapat 4 residu asam amino, yaitu : ARG106, LEU345, TYR790 dan TRP331.

\section{DAFTAR PUSTAKA}

Cahyono B, Huda MDK, Limantara L. 2011. Pengaruh Proses Pengeringan Rimpang Temulawak (Curcuma xanthorriza Roxb) Terhadap Kandungan dan Komposisi Kurkuminoid. Reaktor. 13(3):165-169

Eko T. 2012. Penggunaan Coxib Dalam Tata Laksana Nyeri Nosiseptif. Denpasar. Medicina. 43(1):2330.

Hasanah AN, Nazaruddin F, Febrina E, Zuhrotun A. 2011. Analisis Kandungan Minyak Atsiri dan Uji Aktivitas Antiinflamasi Ekstrak Rimpang Kencur (Kaempferia galanga L.). Jurnal Matematika \& Sains. 16(3):147-152.

Hernani, Winarti C. 2008 (tidak diterbitkan). Kandungan Bahan Aktif Jahe dan Pemanfaatannya Dalam Bidang Kesehatan.. Bogor (ID): Balai Besar Penelitian dan Pengembangan Pascapanen Pertanian. hlm 125142.

Huang N, Shoichet BK, Irwin JJ. 2006. Benchmarking Sets for Molecular Docking. Journal of Medicinal Chemistry. 49:6789-6801.

Meiyanto E. 2011. Harapan dan Tantangan Pengembangan Agen Kemoprevensi Kanker
Tepat Sasaran. [Pidato Pengukuhan Jabatan Guru Besar]. Yogyakarta (ID) : Fakultas Farmasi Universitas Gadjah Mada.

Mumpuni E, Nurrochmad A, Pranowo HD, Jenie UA dan Istyastono EP. 2014. Construction and validation of the structure based virtual screening protocols with PDB code of $3 L N 1$ to discover cyclooxygenase-2 inhibitors. Di dalam The First International Conference on Pharmaceutics and Pharmaceuticals Science (ICPPS), 24-16 Desember 2015. Surabaya (ID): Fakultas Farmasi, Universitas Airlangga. hlm 99 - 101.

Muniroh L, Martini S, Nindya TS, Solfaine R. 2010. Minyak Atsiri Kunyit Sebagai Anti Radang Pada Penderita Gout Artritis Dengan Diet Tinggi Purin. Makara Kesehatan. 14(2):57-64.

Navya A, Jayasimha RD, Devi UM. 2011. Docking Studies on Xanthones of Mangosteen as COX-2 Inhibitors. International Journal of Applied Biology and Pharmaceutical Technology. 2(3):264-267.

[NCI] National Cancer Institute (US). Surveillance, Epidemiology and End Result (SEER). 2010. diperoleh dari: http://www.seer.cancer.gov/search?q=cytotoxic +test. Diakses pada 18 November 2013.

Yuniarti N, Ikawati Z, Istyastono EP. 2011. The Importance of ARG513 as a Hydrogen Bond Anchor to Discover COX-2 Inhibitors in a Virtual Screening Campaign. Bioinformation. 6(4):164166. 